\title{
Uncovering the Function of Taboo Words Used in "Not Another Teen Movie"
}

\author{
Dian Mukti Primasari ${ }^{1}$, Alek $^{2}$, Didin Nuruddin Hidayat ${ }^{3}$, and Dhuha Hadiyansyah ${ }^{4}$ \\ \{dian_mukti17@mhs.uinjkt.ac.id ${ }^{1}$, alek@uinjkt.ac.id², didin.nuruddin@uinjkt.ac.id ${ }^{3}$, atisura@yahoo.co.id ${ }^{4}$ \} \\ ${ }_{1,2,3,4}$ UIN Syarif Hidayatullah Jakarta, Indonesia
}

\begin{abstract}
The study investigated the use of taboo words in a specific movie, namely Not Another Teen Movies. Taboo stimuli are exceptionally stirring, yet it has been recommended that they likewise have inborn explicit properties, for example, taboo, offensiveness, disagreeableness, or even shock value. Nonetheless, taboo words frequently contrast from different words on something beyond excitement and forbidden properties. In the present study, the researchers replicated both of these discoveries and directed detailed item analyses to figure out which word properties drive a few impacts. The study concludes that the taboo words have several functions. Those are expressing desire, insulting people, expressing pride, cursing and disappointment, metaphor, literal meaning, openness, and hatred expression.
\end{abstract}

Keywords: taboo, words analysis, word function

\section{INTRODUCTION}

Swear words and taboo words can heighten what are stated, yet they can stun or give offense. Swearing and the utilization of forbidden words and articulations are very basic in talking. We frequently hear and use them both in private and in open settings and in movies, on TV and on the radio. The utilization of forbidden articulations recommends that speakers have, or wish to have, a nearby close to home association with others [1]. We additionally utilize unthinkable articulations and swear words when we express solid sentiments, or when we wish to undermine or to be upsetting to other people [2].

People employ interjections when swearing [3]. These can be single words or short expressions or provisos. We most regularly use them to express solid sentiments, particularly sentiments of outrage. The quality of the words and articulations here is set apart in stars. An exceptionally solid articulation has five stars and a less solid articulation has one star. Individuals have various perspectives about which articulations are more grounded than others [4].

In the early 2000s, there were a great number of movies which used taboo words especially in the teenager movies, such as American Pie, Saw, Scary movie or even Hangover. The time has changed, so does language preference. Exploring this kind of trend, the researchers were intrigued to access more about the developing language or words choice. Although not all are taboo words, yet in several scenes might be found several or many taboo words used. 


\section{LITERATURE REVIEW}

Taboo words itself, is defined as "a class of emotionally arousing references with respect to body products, body parts, sexual acts, ethnic or racial insults, profanity, vulgarity, slang, and scatology" [5]. It is additionally expressed that while many would concur on the mark of certain words as being "forbidden", there is a deficiency of investigation into the impact of unthinkable words on subjective procedures. In addition, linguist also defining taboo words as "words that sanctioned or restricted on both institutional and individual levels under the assumption that some harm will occur if a taboo word is spoken" [6]. In reality, individuals are commonly reluctant to utilize taboo words, which additionally make their event all the more striking [7]. Other notable linguistics study on taboo argues that the handling of taboo words is affected by particular arrangements of variables, and that taboo words are not only high-excitement enthusiastic words, yet in addition have an inherent taboo property [8]. It was also stated that there are factors which can be simplified related to function of the taboo words [9]. There are desire expression, insults, pride expression, curse, disappointment expression, metaphor, literal meaning, hatred, reference and emphasizing meaning [10].

By having this theory, the researchers would like to explore what are the functions of taboo words used in a movie. The movie chosen is "Not Another Teen Movie" because it is one of the movies launched in the early 2000's. It was when the taboo words were knowingly found on the movie especially for the teenager movies. The objective of this research is to find out the function of the taboo words on the above mentioned movie.

\section{METHODOLOGY \\ 3.1 Research design}

This research study was conducted qualitatively using the literature as the material to be figured out. It consisted of three sequential tasks: (a) watching the movie online, (b) download the subtitle, (c) analyze the subtitle.

Watching the movie. The movie length is about 1:48:00. The researchers watched it from the website of https://indoxx1.com/ then typed the title on the searching panel.

Download the subtitle. The subtitle needed to be downloaded to ease the researchers conducted the analysis. After the movie was successfully downloaded, the data can be researched by highlighting the taboo words. Until then, the file was then printed out. The file was downloaded from http://www.divxmoviesenglishsubtitles.com/N/Not_another_teen_movie.html. It is a free download site base. The subtitle was only provided from 00:00:12,086 until 01:28:58,835

Analyze the subtitle. Analyzing the subtitle by reading the text and highlighting the taboo words. It can be helped also by the searching engine by typing the keywords on the panel before finally found the words desired. The category of taboo words is based on the previous theory. 


\subsection{Participant and the Materials}

In this case the researchers employed movie "Not Another Teen Movie" as the object. A parody of movies marketed to teens, "not another teen movie" depicts what happens when popular jock Jake Wyler (Chris Evans) wagers his companions that he can transform any young lady into the prom ruler just by partner with him - even geeky craftsman Janey Briggs (Chyler Leigh). The film acquires generously both from '80s high schooler works of art like The Breakfast Club, Sixteen Candles, and Pretty in Pink and famous '90s adolescent flicks like 10 Things I Hate About You, Can't Hardly Wait, and Jawbreaker to fiercely parody the stories, characters, and settings that have turned into the signs of the youngster sort. Simultaneously, it spots sex in the frontal area yet not the becoming flushed, credulous interests for the sake of desire and love so normal to high schooler flicks. Or maybe, it selects intergenerational lesbian sex, mother-child and sister-sibling interbreeding, and a lot of extra explicitly express references. Not Another Teen Movie is both uncouth and intemperate. The storyline is mixed with a couple of genuinely amusing references to the racial legislative issues of teenager comedies like Bring It On (where the white team promoters took the moves from a cheerleading squad at a prevalently African-American secondary school). Likewise included are awesome appearances by Paul Gleason (who played the head in The Breakfast Club), Mr. $\mathrm{T}$, and '80s youngster flick staple Molly Ringwald.

Nonetheless, the snapshots of motivation are rare, and they are frequently overwhelmed by the relentless dispatch. What's more, even the interesting bits are best delighted in by those mature enough and develop enough to perceive that the sexual components here are planned to be unnecessary. Families can discuss whether the film is attempting to make a specific point about high school sexuality amidst all its creepiness. The movie was exposing the sexual desire of the teenager. That is why the movie uses so many taboo words to express the message. The writers are the researchers themselves. Hence, the analysis is taken authentically by the researchers.

\section{FINDINGS AND DISCUSSIONS}

The downloaded subtitle is 21 pages. The length of the subtitle is approximately 116 minutes. The commonly found words are mostly related to having sex, bitch, lesbo, whack, shit, damn, fuck, dick-fag, and others. Those words are used for either emphasizing the meaning or only for cursing. It will be shown from the table following.

Table 1: Taboo Words Analysis

\begin{tabular}{|l|l|l|l|l|}
\hline No. & Taboo words & Description & Analysis & Function \\
\hline 1. & $\begin{array}{l}\text { I can't have sex } \\
\text { before you. }\end{array}$ & $\begin{array}{l}\text { The brother of the main character } \\
\text { is underaged. He wants to have } \\
\text { sex with somebody. He stated it to } \\
\text { her sister. }\end{array}$ & $\begin{array}{l}\text { The brother doesn't have any } \\
\text { communication barrier to the } \\
\text { sister. He expressed it openly. }\end{array}$ & $\begin{array}{l}\text { Desire } \\
\text { expression. }\end{array}$ \\
\hline 2. & $\begin{array}{l}\text { More like you're a } \\
\text { lesbo. }\end{array}$ & $\begin{array}{l}\text { The brother said it to the sister } \\
\text { who were captured in in } \\
\text { masturbation. }\end{array}$ & $\begin{array}{l}\text { The brother feel sorry of the } \\
\text { sister's act. He says it because } \\
\text { he worried that the sister } \\
\text { doesn't have any attraction to } \\
\text { the man. }\end{array}$ & Sults \\
\hline 3. & "Damn," "Shit," and & It had been said many times in & Saying it to express the & Curse \\
\hline
\end{tabular}




\begin{tabular}{|c|c|c|c|c|}
\hline & "That is whack!" & many occasions by the cast & $\begin{array}{l}\text { disappointment or curse the } \\
\text { condition. }\end{array}$ & \\
\hline 4. & American pussy. & $\begin{array}{l}\text { It was stated by one of the boys } \\
\text { on the group when they were } \\
\text { chatting. }\end{array}$ & $\begin{array}{l}\text { Express the ability of getting } \\
\text { one of the girls. }\end{array}$ & $\begin{array}{l}\text { Pride } \\
\text { expression }\end{array}$ \\
\hline 5. & Goddamn it & $\begin{array}{l}\text { Yelled many times in the movies. } \\
\text { Especially the boys who were on } \\
\text { the conversation with their } \\
\text { friends. It sated the most among } \\
\text { any taboo words. }\end{array}$ & $\begin{array}{l}\text { Some of the expressions or the } \\
\text { words were used to curse and } \\
\text { some for emphasizing the } \\
\text { deep intention } \\
\text { disappointment. }\end{array}$ & $\begin{array}{l}\text { Curse and } \\
\text { disappointmen } \\
\text { t expression }\end{array}$ \\
\hline 6 & $\begin{array}{l}\text { I'd say you're one } \\
\text { big fucking train } \\
\text { wreck. }\end{array}$ & $\begin{array}{l}\text { Spoken by the one boy who were } \\
\text { about to have bad intention to the } \\
\text { main character. }\end{array}$ & $\begin{array}{l}\text { The expression of pointing the } \\
\text { point or the most crucial part. } \\
\text { Or telling the literal meaning. }\end{array}$ & Metaphor \\
\hline 7. & $\begin{array}{l}\text { I'm going to go fuck } \\
\text { a complete } \\
\text { stranger. }\end{array}$ & $\begin{array}{l}\text { Said by the little brother when he } \\
\text { was on the party. }\end{array}$ & $\begin{array}{l}\text { Literal meaning that he would } \\
\text { try to have sex with } \\
\text { somebody. }\end{array}$ & $\begin{array}{l}\text { Literal } \\
\text { meaning. } \\
\text { openness }\end{array}$ \\
\hline 8. & $\begin{array}{l}\text { Limp-dick fag } \\
\text { fucker! }\end{array}$ & $\begin{array}{l}\text { One of the girls said it to the boy } \\
\text { in the party. Her name was Sandy } \\
\text { Sue. }\end{array}$ & $\begin{array}{l}\text { Expressing the hate of the } \\
\text { speaker to the listener. In this } \\
\text { case the girl to the boy. It is } \\
\text { said so because the girl } \\
\text { considered that the boy is } \\
\text { pervert. }\end{array}$ & Hatred \\
\hline 9. & $\begin{array}{l}\text { Damn, those } \\
\text { bitches represent! }\end{array}$ & $\begin{array}{l}\text { The friend of the main character } \\
\text { said referring to the group of the } \\
\text { girls. }\end{array}$ & $\begin{array}{l}\text { Expressing of reference to the } \\
\text { girls. }\end{array}$ & Reference \\
\hline 10. & $\begin{array}{l}\text { You'll call me a } \\
\text { slut. }\end{array}$ & $\begin{array}{l}\text { Literal meaning had spoken to the } \\
\text { girls who had slept with many } \\
\text { boys in the movie. }\end{array}$ & $\begin{array}{l}\text { Expressing literal meaning to } \\
\text { the cheating girlfriend. }\end{array}$ & $\begin{array}{l}\text { Literal } \\
\text { meaning }\end{array}$ \\
\hline 11. & Son of a bitch! & $\begin{array}{l}\text { The main character said it to the } \\
\text { boy who were trying to steal the } \\
\text { girlfriend. }\end{array}$ & $\begin{array}{l}\text { Expressing disappointed and } \\
\text { curse }\end{array}$ & $\begin{array}{l}\text { Curse and } \\
\text { disappointmen } \\
\text { t expression }\end{array}$ \\
\hline 12. & $\begin{array}{l}\text { I'm not kidding } \\
\text { Somebody please } \\
\text { fucking help me }\end{array}$ & $\begin{array}{l}\text { The main character was asking for } \\
\text { help. The "fucking" word is used } \\
\text { for emphasizing the help. }\end{array}$ & $\begin{array}{l}\text { Emphasizing the intention by } \\
\text { saying taboo word. }\end{array}$ & emphasize \\
\hline
\end{tabular}

From the data above, it was found that the taboo words have several functions. Those are expressing desire, insulting people, expressing pride, cursing and disappointment, metaphor, literal meaning, openness, and hatred expression. Past research taking a gander at contrasts in LD among passionate and impartial words found that distinctions because of feeling were wiped out once the difference clarified by non-enthusiastic word properties was controlled for [11]. This error is most likely because of a mix of methodological and factual contrasts. Methodologically, didn't acquire excitement, valence, and forbidden evaluations, yet rather embraced passionate classifications that were recently decided. The words gave generally communicated the capacity which had been expressed after on the hypothesis part. Those are Desire articulation, affronts, pride articulation, revile, disillusionment articulation, allegory, exacting significance, scorn, reference and underlining meaning. Each capacity at any rate indicated one finding. It is demonstrated that the hypothesis of Christopher is significant and relevant. 


\section{CONCLUSION}

The study was resulting several results that might be beneficial for the words and language analyzers. The present study examines on the early 2000's movie. It is suggested to the other researchers to explore the newest movies as the language has been growing since then. The benefit of the research can be applied for the audience who is considered guidance in-needs, especially the teenager who likes to copy the current popular expressions.

\section{REFERENCES}

[1] Jay, T. B. (2018). Advances in swearing research: New languages and new contexts. Journal of Multilingual and Multicultural Development, 39(8), 752-754.

[2] Jay, T. B. (2009). The utility and ubiquity of taboo words. Perspectives on Psychological Science, 4, 153-161

[3] Allan, K., \& Burridge, K. (2006). Forbidden words: Taboo and the censoring of language. Cambridge, UK: Cambridge University Press.

[4] Madan, C. R., Shafer, A. T., Chan, M., \& Singhal, A. (2017). Shock and awe: Distinct effects of taboo words on lexical decision and free recall. The Quarterly Journal of Experimental Psychology, 70(4), 793-810.

[5] Dhooge, E., \& Hartsuiker, R. J. (2011). How do speakers resist distraction? Evidence from a taboo picture-word interference task. Psychological Science, 22, 855859. https://doi.org/10.1177/0956797611410984.

[6] Ashcraft, C. (2003). Adolescent ambiguities in American Pie: Popular Culture as a resource for sex education. Youth \& Society, 35(1), 3770. https://doi.org/10.1177/0044118X03254558

[7] Hakim, L. (2018). The improvement of English communication competency on spoken and written narrative text through "Movies Cutting" media. Humanis: Jurnal Ilmu-Ilmu Sosial dan Humaniora, 10(1), 27-32.

[8] Larsen, R. J., Mercer, K. A., \& Balota, D. A. (2006). Lexical characteristics of words used in emotional Stroop experiments. Emotion, 6, 62-72.

[9] Brysbaert, M., \& New, B. (2009). Moving beyond Kučera and Francis: A critical evaluation of current word frequency norms and the introduction of a new and improved word frequency measure for American English. Behavior Research Methods, 41, 977-990.

[10] Brysbaert, M., \& Diependaele, K. (2013). Dealing with zero-word frequencies: A review of the existing rules of thumb and a suggestion for an evidence-based choice. Behavior Research Methods, 45, 422-430.

[11] Larsen, R. J., Mercer, K. A., Balota, D. A., \& Strube, M. J. (2008). Not all negative words slow down lexical decision and naming speed: Importance of word arousal. Emotion, 8, 445-452. 